\title{
Development and Validation of Stability Indicating RP- HPLC Method for the Estimation of Cinacalcet Hydrochloride in Bullk and Their Formulations
}

\author{
Nagasarapu Mallikharjuna Rao ${ }^{1, *}$ (iD), Dannana Gowri Sankar ${ }^{2}$ iD \\ 1 Department of Pharmaceutical Sciences, Jawaharlal Nehru Technological University, Kakinada, Andhra Pradesh, India \\ 2 Department of Pharmaceutical Analysis \& Quality Assurance, University College of Pharmaceutical Sciences, Andhra \\ University, Visakhapatnam, Andhra Pradesh, India \\ * Correspondence: mallimpharmmba@gmail.com;
}

Scopus Author ID 56537020600

Received: 03.05.2020; Revised: 24.05.2020; Accepted: 25.05.2020; Published: 27.05.2020

\begin{abstract}
A Simple, selective, accurate, precise, linear, and stability-indicating RP-HPLC method was developed and validated for the estimation of Cinacalcet hydrochloride in bulk and tablet dosage forms. Chromatographic separation was achieved on X-Terra Symmetry C18 $(4.6$ x 150mm; $5 \mu \mathrm{m})$ with mobile phase containing Phosphate buffer: Acetonitrile (40:60 v/v) pH adjusted to $3.0 \pm 0.05$ with diluted ortho-phosphoric acid. The flow rate was maintained at $0.9 \mathrm{~mL} / \mathrm{min}$. The eluent was monitored at $282 \mathrm{~nm}$. Moreover, the retention time of Cinacalcet was 2.8 minutes. The method was validated for linearity, accuracy, precision, and robustness as per ICH guidelines. The developed method was found linear between $25-150 \mu \mathrm{g} / \mathrm{ml}$, and the linear regression coefficient was 0.999 . The $\%$ RSD values are less than $2 \%$ indicating the accuracy and precision of the method. The percentage of recovery was obtained from $98-102 \%$. The system suitability parameters were found to be within the limit. Forced degradation studies were conducted under various conditions. The proposed method is simple, rapid, precise, and accurate. It can be used for the quantitation of Cinacalcet hydrochloride in bulk and commercial pharmaceutical dosage forms.
\end{abstract}

Keywords: Cinacalcet Hydrochloride, Method development, Validation, Stability-indicating, ICH Guidelines, RP-HPLC.

(C) 2020 by the authors. This article is an open-access article distributed under the terms and conditions of the Creative Commons Attribution (CC BY) license (https://creativecommons.org/licenses/by/4.0/).

\section{Introduction}

Cinacalcet hydrochloride is a calcimimetic used for the treatment of secondary hyperthyroidism in patients to reduce hypercalcemia. Chemically, cinacalcet hydrochloride is (R)- $N$-[1-(1-naphthyl)ethyl]- 3-[3-(trifluoromethyl) phenyl]propan-1-amine (Fig.1).The molecular formula is $\mathrm{C}_{22} \mathrm{H}_{22} \mathrm{~F}_{3} \mathrm{~N}$, and the molecular weight is $357.412 \mathrm{~g} / \mathrm{mol}$. Cinacalcet hydrochloride is the first of a new class of drugs, the calcimimetics, which acts by increasing the sensing receptors in the parathyroid gland [1-3]. It is also used in the treatment of hypercalcemia in patients with parathyroid carcinoma. Overdose may lead to tachycardia, severe hypotension, and convulsions. A literature survey revealed that very few analytical methods had been reported for the determination of Cinacalcet in pure drug, pharmaceutical dosage forms, and biological samples using liquid chromatography and tandem mass spectrometry [4-24]. The developed RP-HPLC method was simple, fast, accurate, and stability- 
indicating. The developed method was useful for the determination of Cinacalcet hydrochloride in bulk and tablet dosage forms.

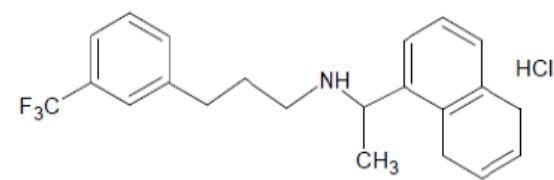

Figure 1. Chemical Structure of Cinacalcet Hydrochloride.

\section{Materials and Methods}

\subsection{Chemicals and reagents.}

Cinacalcet hydrochloride reference standard was received as a gift sample from Dr. Reddy's Laboratories, Hyderabad, India. All chemicals and reagents used for the analysis are HPLC grade.

\subsection{Instrumentation.}

HPLC analysis was performed on Waters HPLC e2695 series consisting of pump, autosampler, UV-Vis detector, with Empower 2 software.

\subsection{Buffer preparation.}

Weighed and transferred 7.0 grams of Potassium dihydrogen phosphate into a $1000 \mathrm{~mL}$ beaker, dissolved and diluted to $1000 \mathrm{~mL}$ with HPLC water. Adjusted the $\mathrm{pH}$ to $3.0 \pm 0.05$ with orthophosphoric acid; Diluent: Mobile phase.

\subsection{Standard stock solution preparation.}

$10 \mathrm{mg}$ of Cinacalcet working standard was weighed accurately and transferred into a $100 \mathrm{~mL}$ volumetric flask, dissolved in $60 \mathrm{ml}$ of diluent and diluted the volume up to the mark with diluent and mixed well. $1.5 \mathrm{~mL}$ of the standard stock solution was diluted to, in a $10 \mathrm{~mL}$ volumetric flask, and mixed well.

\subsection{Sample preparation.}

Weighed twenty Cinacalcet hydrochloride tablets, and the average weight was calculated. Accurately weighed and transferred the sample equivalent to $10 \mathrm{mg}$ of Cinacalcet into a $100 \mathrm{~mL}$ volumetric flask. Added about $70 \mathrm{~mL}$ of diluent and sonicated to dissolve entirely and made the volume up to mark with diluent. Mixed well and filtered through a 0.45 $\mu \mathrm{m}$ filter. Further pipetted $1.5 \mathrm{~mL}$ of the above stock solution into a $10 \mathrm{~mL}$ volumetric flask and diluted up to the mark with diluent. Mixed well and filtered through $0.45 \mu \mathrm{m}$ filter.

2.6. Assay of Cinacalcet HCL (\% of label claim).

Assay value in mg/tablet (rounded off value)/Label Claim X 100. 


\section{Results and Discussion}

\subsection{Method development.}

RP- HPLC method was developed, keeping in mind the system suitability parameters, i.e., tailing factor $(\mathrm{T})$, number of theoretical plates $(\mathrm{N})$, run time, and cost-effectiveness.

\subsubsection{Optimized chromatographic conditions.}

Chromatography was achieved on Symmetry C18 (4.6 x 150mm, $5 \mu \mathrm{m}$, Make: XTerra) with a mobile phase containing Phosphate buffer $\mathrm{pH} 3.0 \pm 0.05$ (adjusted with orthophosphoric acid), and Acetonitrile in the ratio of $40: 60 \mathrm{v} / \mathrm{v}$ at a flow rate of $0.9 \mathrm{~mL} / \mathrm{min}$. The eluent was monitored at $282 \mathrm{~nm}$. The injection volume was $20 \mu \mathrm{l}$, and the column temperature was maintained at $30^{\circ} \mathrm{c}$. The optimized, developed method resulted in the elution of Cinacalcet at a retention time of $2.8 \mathrm{~min}$. Figure 2 represents the chromatogram of the standard solution.

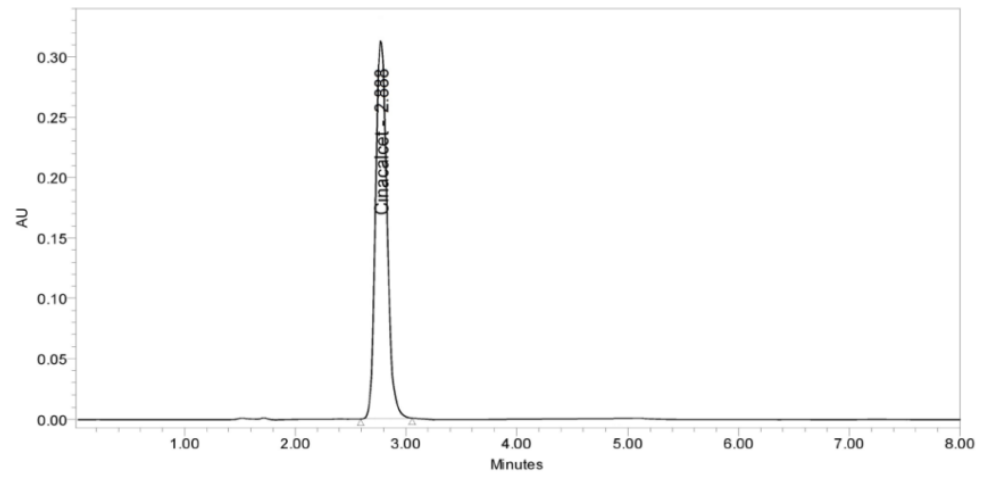

Figure 2. Typical chromatogram of the standard solution

The total run time was maintained as 8 minutes. System suitability tests are used to ensure the adequate performance of the chromatographic system. Retention time, the number of theoretical plates, and peak tailing factor $(\mathrm{T})$ were evaluated for six replicate injections of the standard at working concentration. The results are given in Table 1.

Table 1. System suitability results of Cinacalcet.

\begin{tabular}{c|c}
\hline Parameters & Cinacalcet \\
\hline Retention time (min) & 2.885 \\
\hline Number of Theoretical plates (N) & 6632 \\
\hline Tailing factor (T) & 1.05 \\
\hline
\end{tabular}

In order to verify the applicability of the developed method to a commercial formulation, 'CAPICET' was analyzed at working concentration and shown in Figure 3.

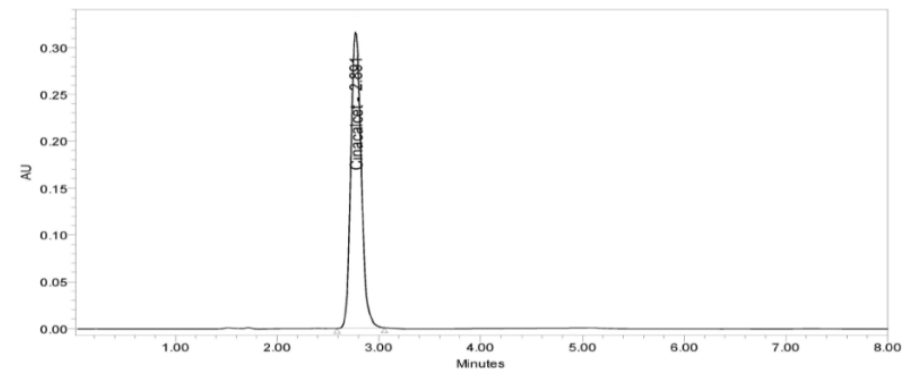

Figure 3. Typical chromatogram of the sample solution.

The analyte peak in the sample was identified by comparing the retention time with the standard drug. System suitability parameters were found within the acceptable limits. The 
integration of separated peak area was done, and drug concentration was determined by using the peak area concentration relationship obtained in the standardization step. The assay of the drug in the sample ranging between 98.0 and $102.0 \%$, which is the standard and acceptance level in any pharmaceutical quality control laboratory. The results are given in Table 2.

Table 2. Assay results of Cinacalcet.

\begin{tabular}{c|c|c|c|c}
\hline TABLET & Label Claim $(\mathbf{m g})$ & $\begin{array}{c}\text { Amount found } \\
(\mathbf{m g} / \text { tablet })\end{array}$ & $\begin{array}{c}\text { \% Label claim* } \\
\text { S.D. }\end{array}$ & \% recovery \\
\hline Capicet & 30 & 30.01 & $99.85 \pm 0.1247$ & 100.86 \\
\hline
\end{tabular}

*average of three determinations

\subsection{Method validation.}

Validation of the developed method was performed in order to prove that the method was suitable for its intended use. The method was validated according to the International Conference on Harmonization (ICH) guidelines for validation of analytical procedures [25-26]. The method was validated for the system suitability, specificity, linearity, accuracy, precision, ruggedness, robustness.

\subsubsection{Specificity.}

The specificity of the analytical method is its capability to measure analyte precisely and particularly in the presence of other components that may be likely to be present in the sample matrix. Chromatograms of blank (Figure 4) proves that the method was specific.

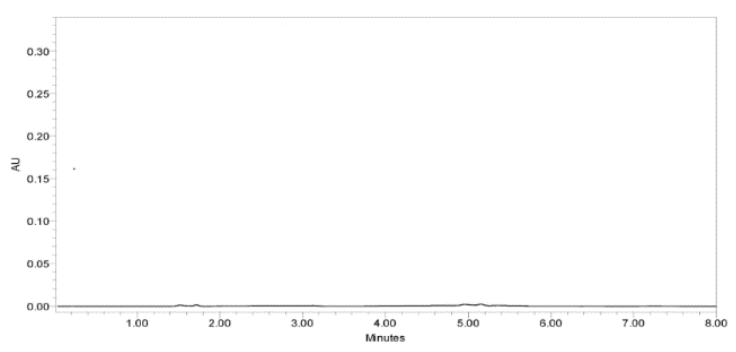

Figure 4. Specificity Chromatogram of Cinacalcet.

\subsubsection{System precision.}

Injected six replicate injections of the standard solution at working concentration showed \% RSD (Relative Standard Deviation) less than 2.0, which indicates the acceptable reproducibility and thereby the precision of the system.

\subsubsection{Method precision.}

Method precision was determined under the tests of (i) repeatability (Intra-day precision) and (ii) Intermediate precision/ Ruggedness/ Inter day precision performed at working concentration by different analysts on different instruments with columns of different lot numbers.

\subsubsection{Repeatability (Intra-day precision).}

The intraday precision was determined with six assay preparations of the Cinacalcet test solution with respect to the valid working standard. The \% RSD for six assay results was 
less than $2 \%$, which indicates that the developed method is precise by the test of repeatability. The results were tabulated in table 3 .

3.2.5. Intermediate Precision (Ruggedness / Inter day precision).

Intermediate precision was evaluated by performing method precision on different days by different analysts, showed \% RSD less than 2, which indicates the method developed is precise or rugged. The results were tabulated in table 3.

Table 3. Precision results of Cinacalcet.

\begin{tabular}{c|c|c|c|c}
\hline \multirow{2}{*}{ S.NO. } & \multicolumn{2}{|c|}{ Intraday precision } & \multicolumn{2}{c}{ Inter day precision } \\
\cline { 2 - 5 } & Peak Area & \% Assay & Peak Area & \% Assay \\
\hline 1 & 3737080 & 102.1 & 3759451 & 102.7 \\
\hline 2 & 3728170 & 102.0 & 3763697 & 102.8 \\
\hline 3 & 3738936 & 102.5 & 3768477 & 102.8 \\
\hline 4 & 3732249 & 102.4 & 3759499 & 102.9 \\
\hline 5 & 3754858 & 102.4 & 3777152 & 103.0 \\
\hline 6 & 3762639 & 102.8 & 3785054 & 103.2 \\
\hline AVG & 3742322 & 102.4 & 3768888 & 102.9 \\
\hline STDEV & 13495.33 & 0.288 & 10334.01 & 0.179 \\
\hline$\%$ RSD & 0.36 & 0.28 & 0.27 & 0.17 \\
\hline
\end{tabular}

\subsubsection{Linearity.}

The linearity plot was constructed with six concentrations at $25-150 \%$ levels $(5,10,15$, 20,25 , and $30 \mu \mathrm{g} / \mathrm{mL}$ of $\mathrm{CIN}$ ). The calibration curve was constructed by plotting the concentration level of the drug versus the corresponding peak area. The results proved that an excellent correlation between peak area and concentration level of the drug within the concentration range and the results are given in Tables 4 to 5 and Figure 5 . The correlation coefficient was found to be 0.999 , which meets the method validation acceptance criteria. Hence, the method is said to be linear.

Table 4. Linearity of the chromatography system.

\begin{tabular}{c|c|c|c|c}
\hline Drug & $\begin{array}{c}\text { Linearity range } \\
(\boldsymbol{\mu} \mathbf{g} / \mathbf{m l})\end{array}$ & $\mathbf{R}^{\mathbf{2}}$ & Slope & Intercept \\
\hline Cinacalcet & $5-30$ & 0.999 & 249748 & 58816 \\
\hline
\end{tabular}

Table 5. Calibration data for Cinacalcet.

\begin{tabular}{c|c|c}
\hline $\boldsymbol{( \% ) L e v e l ~}$ & $\begin{array}{c}\text { Concentration range } \\
(\boldsymbol{\mu g} / \mathbf{m l})\end{array}$ & Peak area \\
\hline L1-25\% & 5 & 1250028 \\
\hline L2-50\% & 10 & 2405987 \\
\hline L3-75\% & 15 & 3665123 \\
\hline L4-100\% & 20 & 4828439 \\
\hline L5-125\% & 25 & 6297338 \\
\hline L6-150\% & 30 & 7423736 \\
\hline
\end{tabular}

\subsubsection{Accuracy.}

Accuracy was determined through recovery experiments, by the determination of $\%$ mean recovery of the sample at three different levels (50-150\%). At each level, three determinations were performed. Percent mean recovery was calculated, as shown in Table 6 . The accepted limits of recovery are $98 \%-102 \%$ and all observed data are within the required range, which indicates good recovery values, and hence the accuracy of the method developed. 


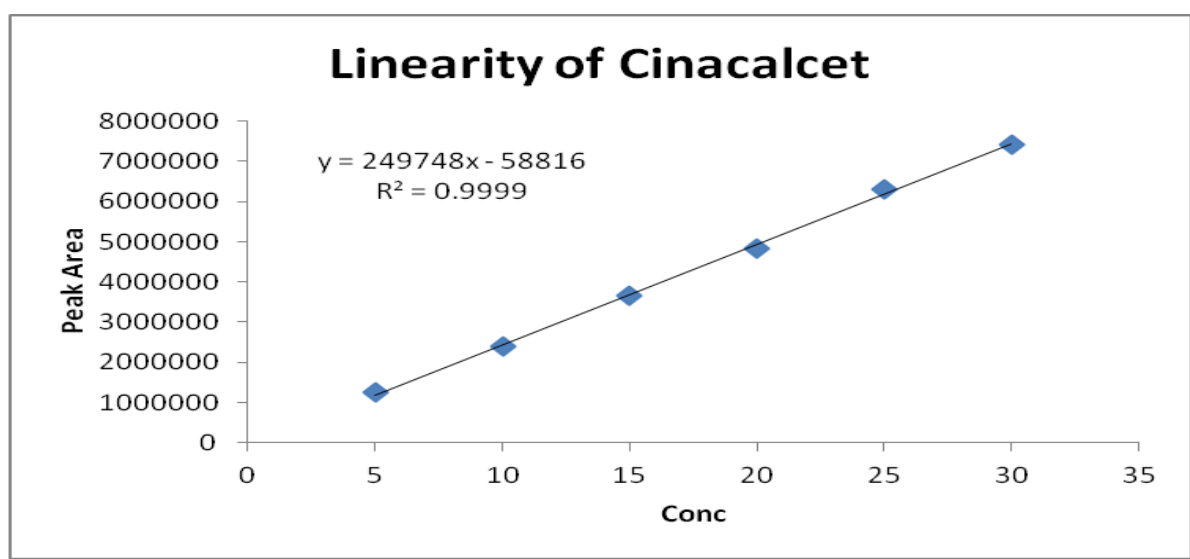

Figure 5. Calibration graph of Cinacalcet

Table 6. Results of Accuracy studies for Cinacalcet

\begin{tabular}{c|c|c}
\hline $\begin{array}{c}\text { Concentration Level } \\
(\%)\end{array}$ & Area & *\%Mean Recovery \\
\hline 50 & 1832703 & 101.37 \\
\hline 100 & 3588525 & 100.13 \\
\hline 150 & 5379174 & 101.07 \\
\hline
\end{tabular}

*Mean of three replicates

\subsubsection{Robustness.}

The robustness of the method was evaluated by assaying test solutions after slight but deliberate changes in the analytical conditions like flow rate, wavelength, and temperature. System suitability data was found to be satisfactory during the variation of the analytical conditions. Results of system suitability show that the analytical method remained unaffected by slight but deliberate changes in the analytical conditions. The results were summarized in table 7 .

Table 7. Evaluation data of robustness study of Cinacalcet

\begin{tabular}{c|c|c|c|c}
\hline \multirow{2}{*}{ Robust conditions } & \multirow{2}{*}{ Rt (min) } & \multirow{2}{*}{ Peak area } & \multicolumn{2}{|c}{ System-suitability parameters } \\
\cline { 4 - 5 } & & & Theoretical Plates & Tailing factor \\
\hline Temp $25^{\circ} \mathrm{C}$ & 3.124 & 3495145 & 6574 & 1.05 \\
\hline Temp $30^{\circ} \mathrm{C}$ & 2.881 & 3435628 & 6570 & 1.02 \\
\hline Temp $35^{\circ} \mathrm{C}$ & 2.552 & 3691542 & 6715 & 1.08 \\
\hline Flow $0.9 \mathrm{~mL} / \mathrm{min}$ & 3.261 & 3586472 & 6659 & 1.01 \\
\hline Flow $1.0 \mathrm{~mL} / \mathrm{min}$ & 2.881 & 3435628 & 6570 & 1.02 \\
\hline Flow $1.1 \mathrm{~mL} / \mathrm{min}$ & 2.456 & 3610472 & 6625 & 1.02 \\
\hline Less wavelength $280 \mathrm{~nm}$ & 2.765 & 3345892 & 6587 & 1.03 \\
\hline wavelength $282 \mathrm{~nm}$ & 2.881 & 3435628 & 6570 & 1.02 \\
\hline More wavelength $284 \mathrm{~nm}$ & 2.881 & 3563544 & 6642 & 1.03 \\
\hline
\end{tabular}

\subsubsection{Forced degradation.}

Forced degradation study was performed to evaluate the stability of the developed method using the stress conditions like the exposure of sample solution to acid $(0.1 \mathrm{~N} \mathrm{HCl})$, base $(0.1 \mathrm{~N} \mathrm{NaOH})$, peroxide $\left(3 \% \mathrm{H}_{2} \mathrm{O}_{2}\right)$, thermal ( at $50^{\circ} \mathrm{c}$ for $24 \mathrm{hrs}$.) and $\mathrm{UV}$ ( exposed to UV light for 7 days). In each degradation condition, no interference was observed with the analyte peak. Figure 6-10 represents the degradation of chromatograms and their purity plots. In each degradation study, it was observed that the purity threshold is greater than the purity angle. It indicates that the peak was said to be pure. The results are presented in Table 8. 

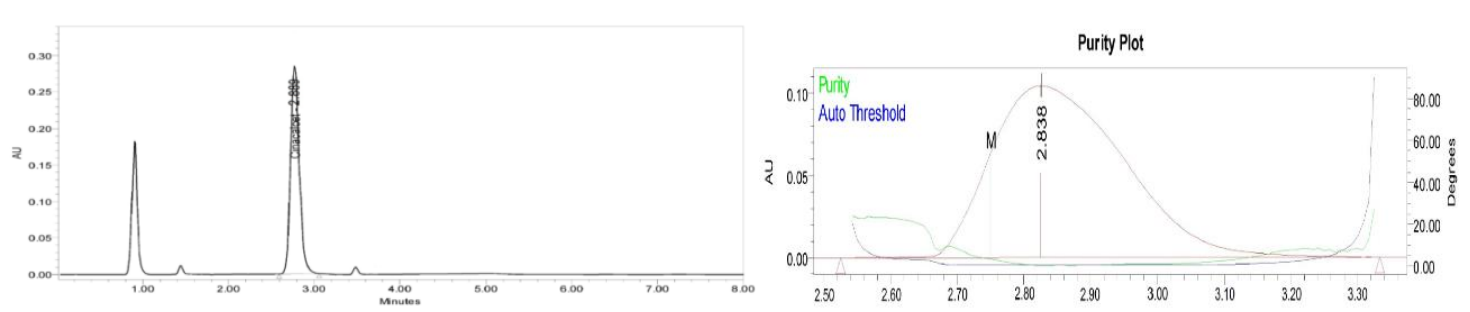

Figure 6. Acid Degradation chromatogram and purity plot.
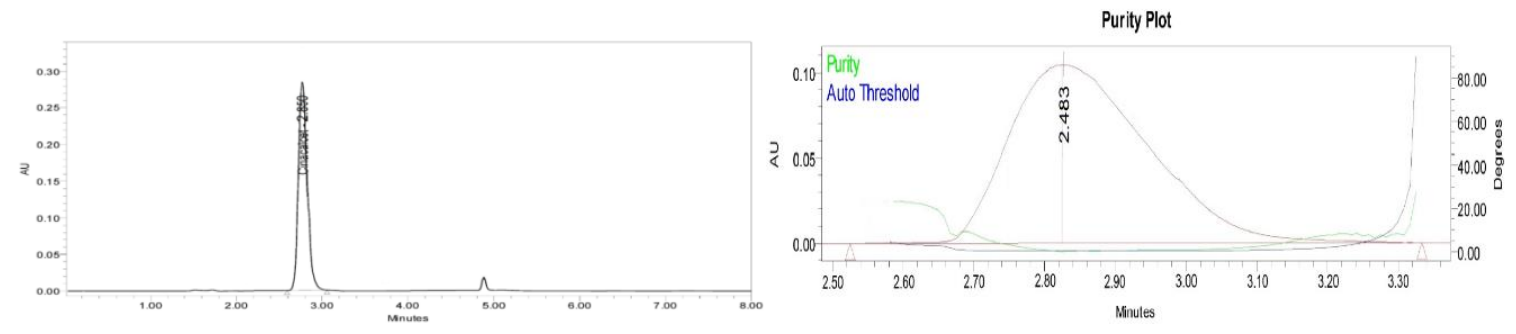

Figure 7. Base Degradation chromatogram and purity plot.

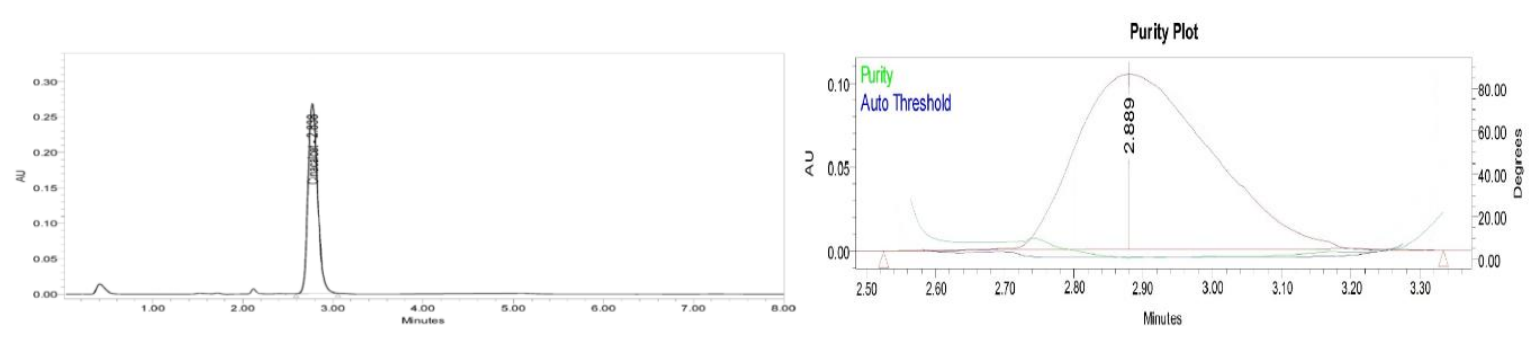

Figure 8. Peroxide Degradation chromatogram and purity plot.
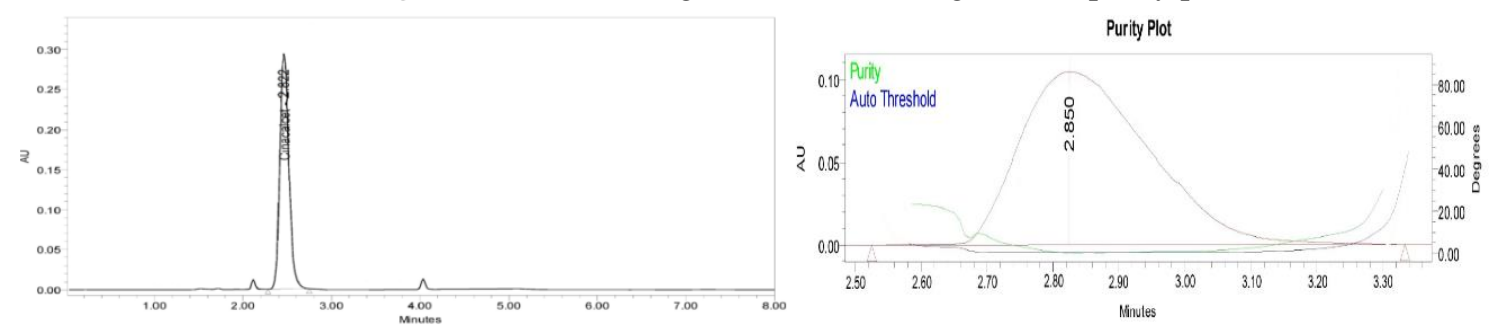

Figure 9. Thermal Degradation chromatogram and purity plot.
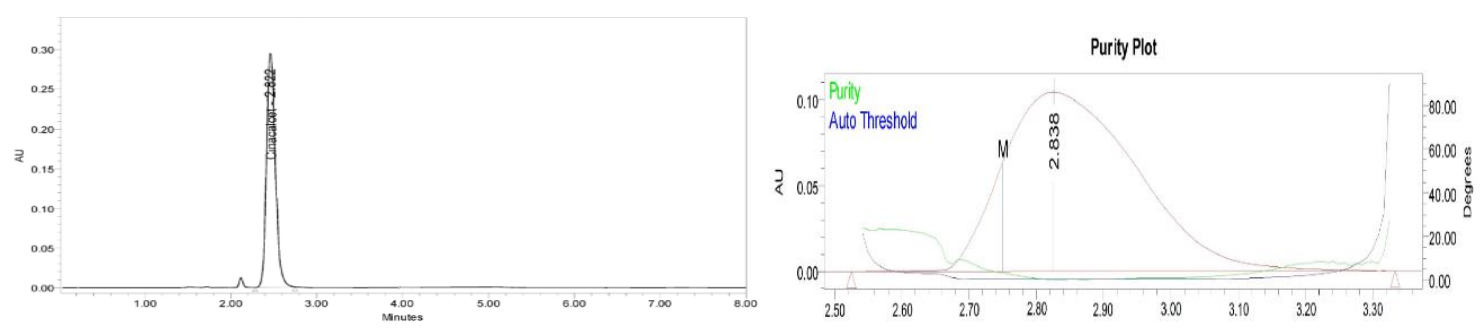

Figure 10. UV Degradation chromatogram and purity plot.

Table 8. Results of Degradation studies for Cinacalcet

\begin{tabular}{c|c|c|c|c}
\hline $\begin{array}{c}\text { Nature of the } \\
\text { Sample }\end{array}$ & \% Assay & \% Degradation & Purity angle & $\begin{array}{c}\text { Purity } \\
\text { threshold }\end{array}$ \\
\hline Acid & 87.47 & -12.53 & 0.114 & 0.232 \\
\hline Base & 89.73 & -10.27 & 0.232 & 0.546 \\
\hline Thermal & 90.87 & -9.13 & 0.223 & 0.643 \\
\hline Peroxide & 92.9 & -7.1 & 0.104 & 0.294 \\
\hline UV & 90.75 & -9.25 & 0.285 & 0.632 \\
\hline
\end{tabular}




\section{Conclusions}

The developed method proved that less consumption of organic phase; hence the method was economical. A good linear relationship was found for the drug between concentration ranges of 5 to $30 \mu \mathrm{g} / \mathrm{ml}$. The inter-day and intraday precision results were found satisfactory proved that the developed method is precise and reproducible because of the low $\%$ RSD (below 2\%). Accuracy studies revealed that mean recoveries were between 98.0 and $102.0 \%$, and indicative of the accurate method. No variation was observed in the system suitability results even after small, deliberate changes were made in the flow rate and temperature; hence the method was robust. Degradation studied is performed under different conditions like acid, base, peroxide, UV, and thermal. In each degradation study, it was observed that the purity angle is less than the threshold value. It indicated the no interference of degradants with the drug peak, so the peak was said to be pure. Degradation studies proved that the developed method was stability-indicating.

A stability-indicating and economic RP-HPLC method were developed and validated as per ICH guidelines in terms of specificity, accuracy, precision, linearity, ruggedness, robustness for the quantitative estimation of Cinacalcet in tablets.

\section{Funding}

This research received no external funding.

\section{Acknowledgments}

The authors are thankful to Vice President, R\&D, Dr. Reddy's Laboratories for providing the gift sample of Cinacalcet Hydrochloride. I would also extend my thanks to JNTUK and Andhra University for providing the facilities to carry out the research work.

\section{Conflicts of Interest}

The authors declare no conflict of interest.

\section{References}

1. Nirogi, R.; Vishvottam, K.; Komarneni, P.; Aleti, R.; Kalaikadiban, I. Quantification of cinacalcet by LCMS/MS using liquid liquid extraction from $50 \mathrm{~L}$ of plasma. J. Pharm. Biomed. Analysis 2011, 56, 373-381, https://doi.org/10.1016/j.jpba.2011.05.032.

2. Yang, F.; Wang, H.; Zhao, Q.; Liu, H.; Hu, P.; Jiang, J. Determination of cinacalcet hydrochloride in human plasma by liquid chromatography-tandem mass spectrometry. Journal of Pharmaceutical and Biomedical Analysis 2012, 61, 237-241, https://doi.org/10.1016/j.jpba.2011.10.022.

3. Rey, G. Cinacalcet for secondary hyperparathyroidism in patients receiving hemodialysis. New Eng. J. Med. 2004, 1, 250-262, https://doi.org/10.1056/NEJMoa031633.

4. Sigala, A.; Raghunath, V.; and Varma, M.; Balaswamy, G. New validated liquid chromatographic method for the determination of impurities in cinacalcet hydrochloride. Anal. Chem. Indian J. 2009, 8, 594-599.

5. Manikandan, K.; Santhana Lakshmi, L.; Gayatri, S.; Akshita, Y. Stability indicating HPLC method for the estimation of cinacalcet hydrochloride API. Ind. J. Res. Pharm. Biotech. 2013, 1, 346-350.

6. Eswara Rao, B.; Lakinani, V.; David Krupadanam Gazula, L. Method development and validation and degradation studies for Cinacalcet Hcl drug by RP-HPLC method. Int. J. Chem. Pharm. Sci. 2014, 2, 990996.

7. Radhika, T.; Vanitha Prakash, K.; Susena, S.; Tejaswini, R. Validated RP-HPLC method for the estimation of Cinacalcet in bulk and tablet dosage form. Ame. J. Pharm. Tech. Res. 2013, 3, 409-414.

8. Siva Ganesh, N.; Ratanlal, M.; Narasaiah, V.; Spandana, D.; Sridhar, T.; Sagar, N. Development and validation RP-HPLC method for estimation of Cinacalcet in bulk and tablet dosage form. Ame. J. Pharm. Tech. Res. 2015, 5, 454-463. 
9. Amruta, B.; L, Minal, R.; Sawant. D. Spectrophotometric estimation of Cinacalcet hydrochloride in bulk and tablet dosage forms. Int. J. Pharm. Pharm. Sci. 2012, 3, 513-515.

10. Manjula, A.; Chandana Deepthi, G.; Vijayaraj, S. Spectrophotometric determination of cinacalcet hydrochloride in bulk. Int. J. Pharm. Rev. Res. 2012, 2, 111-118.

11. Sunil Reddy, P.; Rahava Raju, T.; Satyanarayana Raju, P. Development and Validation of a StabilityIndicating RP-UPLC Method for the Estimation of Impurities in Cinacalcet Hydrochloride API and its Formulation. Scientia Pharmaceutica 2015, 83, 583-598, https://doi.org/10.3797/scipharm.1502-06.

12. Mona, A.; Ibrahim, D.; Maha, S.; Nourah, A. Determination of Cinacalcet Hydrochloride by Capillary Electrophoresis with Photodiode Array Detection. Instrumentation Sci. and Tech. 2014, 42, 27-37, https://doi.org/10.1080/10739149.2013.832292.

13. Mallikarjuna Rao, N.; Gowrisankar, D. Development and validation of novel stability indicating UV spectrophotometric method fo the estimation of Cinacalcet hydrochloride in bulk and tablet dosage forms. Indian Drugs 2016, 53, 31-36.

14. Farnoudiyan, H.; Jaymand, M. Separation and quantitative determination of cinacalcet metabolites in urine sample using RP-HPLC after derivation with a fluorescent labeling reagent. Journal of chromatography $B$. 2016, 1027, 214-220, https://doi.org/10.1016/j.jchromb.2016.05.047.

15. Debadash, P.; Amiyakanta, M.; Sushant, S. Development and validation of a rp-hplc method for quantitative estimation of cinacalcet in tablet dosage form. World J. of Pharm Res. 2018, 19, 1016-1025.

16. Kara Thomson, S.; David, H.; Lipika, C. Stability of extemporaneously prepared cinacalcet oral suspensions. American Journal of Health-System Pharmacy 2018, 9, 236-240, https://doi.org/10.2146/ajhp170072.

17. Bjorn, S.; Sergio, I.; Ron, A.; Michael, A. A Decision-analytic to assess the cost effectiveness of etelcalcetide vs. Cinacalcet. PharmacoEconomics 2018, 36, 603-612.

18. Swetha, K.; Veeresham, C. Determination and Validation of HPTLC Method for Cinacalcet Hydrochloride. American J. of Anal. Chem. 2019, 10, 55-64, https://doi.org/10.4236/ajac.2019.102005.

19. Ping, C.; Winnie, S.; Adimoolam, N.; Murad, M. Bridging adults and paediatrics with secondary hyperparathyroidism receiving haemodialysis: a pharmacokinetic-pharmacodynamic analysis of cinacalcet. British Journal of Clinical Pharmacology 2019, 85, 1312-1325, https://doi.org/10.1111/bcp.13900.

20. Douglas, S.; Shan, X.; Vasily, B.; Hal, M. Variability in cinacalcet prescription across US hemodialysis facilities. Clin. J. of American Soc. of Neph. 2019, 14, 241-249, https://doi.org/10.2215/CJN.09550818.

21. Winnie, Y.; Anthony, A.; Isidro, B. An open-label, single-dose study to evaluate the safety, tolerability, pharmacokinetics, and pharmacodynamics of cinacalcet in pediatric subjects aged 28 days to $<6$ years with chronic kidney disease receiving dialysis. Pediatric Nephrology 2019, 34, 145-154, https://doi.org/10.1007/s00467-018-4154-5.

22. Kara, T.; David, J.; Pharm, D.; Lipika, C. Stability of extemporaneously prepared cinacalcet oral suspensions. American Journal of Health-System Pharmacy 2018, 75, 236-240, https://doi.org/10.2146/ajhp170072.

23. Bradley, A.; Janet, N.; Gema, A.; Bastian, D.; Franz, S. A randomized, double-blind, placebo-controlled study to assess the efficacy and safety of cinacalcet in pediatric patients with chronic kidney disease and secondary hyperparathyroidism receiving dialysis Pediatric Nephrology 2019, 34, 475-486, https://doi.org/10.1007/s00467-018-4116-y.

24. Andrew, H.; Vasily, B.; David, Feeny. Comparison of health state utility estimates from instrument-based and vignette-based methods: a case study in kidney disease BMC Research Notes 2019, 12, 385-392, https://doi.org/10.1186/s13104-019-4413-y.

25. ICH Harmonized Tripartite Guideline: Text on Validation of Analytical Procedures, Text and Methodology, Q2(R1). International Conference on Harmonization, Geneva 2005, 1-17.

26. ICH Harmonized Tripartite Guideline: Stability Testing of New Drug Substances and Products, Q1A(R2). International Conference on Harmonization, Geneva 2003, 1-24. 